\title{
PENERAPAN MODEL PEMBELAJARAN KOOPERATIF TIPE TALKING STICK DAPAT MENINGKATKAN HASIL BELAJAR IPS SISWA KELAS VB SDIT INSAN UTAMA PEKANBARU
}

\author{
Elfi Rahmi, Nelda Azriani, Hendri Marhadi, Neni Hermita
}

Pendidikan Guru Sekolah Dasar FKIP Universitas Riau

elfirahmi@yahoo.com, neldaazriani15@gmail.com, nenihermita1@gmail.com,

\begin{abstract}
This study is based on the low learning student's social science outcomes. The purpuse of this study is to improve the learning outcomes of IPS with the implementation of cooperative learning model type talking stick, each cycle of two meetings and one time test. This study was conduted on 23 subjects of primary school students' in SDIT Insan Utama Pekanbaru. Result of this research obtained average student's learning outcomes 76,73 with enough categories and on the second cycle student's learning outcomes increase to 82,17 categorized well. This suggest that the cooperative model type talking stick can improve the learning outcomes of IPS on the Primary School Students.
\end{abstract}

Keywords: Cooperative Model, Type Talking Stick, Learning Outcomes of IPS

\section{PENDAHULUAN}

IPS adalah salah satu mata pelajaran yang berusaha membekali wawasan dan keterampilan peserta didik sekolah agar mampu beradaptasi dan bermasyarakat serta menyesuaikan dengan perkembangan di era globalisasi. Melalui mata pelajaran ilmu pengetahuan sosial, peserta didik diarahkan, dibimbing, dan dibantu untuk menjadi warga negara Indonesia yang baik dan warga dunia yang efektif (Depdiknas, 2006).

Mata pelajaran IImu Pengetahuan Sosial disusun secara sistematis, komprehensif, dan terpadu dalam proses pembelajaran untuk menuju kedewasaan dan keberhasilan dalam kehidupan di masyarakat. Tujuan dari mata pelajaran IPS yakni mengembangkan potensi peserta didik agar peka terhadap masalah sosial yang terjadi di masyarakat, memiliki sikap mental positif, dan terampil mengatasi setiap masalah baik yang menimpa dirinya sendiri maupun yang menyangkut masyarakat.

Menyadari pentingnya pelajaran IPS, maka mata pelajaran IPS sangat penting diberikan bagi siswa SD, karena siswa diajarkan untuk mengenal 
lingkungan sosial di sekitarnya dan untuk dapat menjalani kehidupan yang baik di tengah-tengah lingkungan sosial tersebut. Dengan mempelajari IPS, diharapkan siswa dapat berlatih untuk memahami lingkungan sosialnya dan untuk dapat bermasyarakat (Wahidmurni, 2017). Namun hal ini tidak berjalan sebagaimana mestinya karena jika dilihat dari proses belajar saat ini, kualitas pembelajaran IPS masih sangat rendah. Proses belajarnya masih berfokus pada penguasaan materi saja dengan metode ceramah. Metode ceramah tentunya akan membuat siswa menjadi pendengar yang pasif yang menekan siswa untuk memperoleh pelajaran melalui pendengaran sehingga bersifat menghapal. Proses belajar seperti ini tidak dapat menjadikan pembelajaran yang efektif untuk siswa menguasai pelajaran secara utuh, karena pada hakikatnya menghapal merupakan keterampilan mengingat yang memiliki retensi terbatas (Hermita, N. 2017). Hal ini tentunya akan berdampak pada hasil belajar siswa (Guslinda, 2018).

Berdasarkan hasil observasi dilapangan dengan ibu Nurida Fatmiwati S.Pd selaku wali kelas V B Sekolah Dasar Islam Terpadu (SDIT) Insan Utama Pekanbaru tahun 2017 hasil belajar IPS masih rendah, masih banyak diantara siswa tersebut yang tidak mencapai. Untuk lebih jelasnya dapat dilihat pada tabel berikut ini :

\section{Tabel 1}

Ketuntasan siswa kelas V B SDIT Insan Utama Pekanbaru pada mata pelajaran IPS

\begin{tabular}{|c|c|c|c|c|}
\hline $\begin{array}{c}\text { Jumlah } \\
\text { Siswa }\end{array}$ & KKM & $\begin{array}{c}\text { Jumlah } \\
\text { Siswa Tuntas }\end{array}$ & $\begin{array}{c}\text { Jumlah } \\
\text { Siswa Belum Tuntas }\end{array}$ & Rata-rata \\
\hline 23 & 75 & $10(43,48 \%)$ & $13(56,52 \%)$ & 68,91 \\
\hline
\end{tabular}

Berdasarkan tabel di atas dapat diketahui tingkat keberhasilan proses pembelajaran IPS pada sekolah tersebut masih rendah atau belum mencapai keberhasilan maksimal. Ini akan menjadi tantangan bagi guru untuk dapat meningkatkan hasil belajar IPS siswa sehingga mencapai keberhasilan maksimal. Salah satu cara yang dapat dilakukan guru adalah dengan menerapkan model pembelajaran yang dapat menjadikan pembelajaran efektif sehingga siswa tidak 
lagi menjadi pendengar pasif didalam proses belajar. Model yang tepat untuk diterapkan pada pelajaran IPS yaitu model pembelajaran Talking Stick atau yang biasa disebut dengan tongkat berbicara dengan bantuan media Lembar Kerja Siswa yang biasa disebut dengan LKS. Menurut Suprijono (2011) model pembelajaran talking stick diawali dengan penjelasan guru mengenai materi pokok yang akan dipelajari. Siswa diberi kesempatan membaca dan mempelajari materi tersebut. Guru selanjutnya meminta kepada siswa menutup bukunya. Dalam hal ini agar mampu meningkatkan keaktifan siswa dan mampu menjawab pertanyaan dengan baik dan benar khususnya pada mata pelajaran IPS.

Berdasarkan permasalahan yang telah diuraikan di atas, maka penelitian ini bertujuan untuk mengetahui: peningkatan hasil belajar IPS dengan penerapan model pembelajaran kooperatif tipe talking stick.

\section{METODE PENELITIAN}

Penelitian ini dilaksanakan pada bulan April - Mei 2018 semester genap tahun ajaran 2017/2018 pada mata pelajaran IPS. Subjek penelitian ini adalah siswa kelas V B SDIT Insan Utama Pekanbaru yang berjumlah 23 siswa yang terdiri dari 10 siswa perempuan dan 13 siswa laki-laki. Metode yang digunakan pada penelitian di SDIT Insan Utama Pekanbaru adalah Penelitian Tindakan Kelas (Classroom Action Research). Menurut Suharsimi Arikunto (2010) penelitian tindakan kelas adalah suatu pencermatan terhadap kegiatan belajar berupa sebuah tindakan yang sengaja dimunculkan dan terjadi dalam sebuah kelas. Desain penelitian tindakan kelas adalah model siklus dengan dua siklus, yaitu siklus I dan siklus II. Siklus I terdiri dari: perencanaan, pelaksanaan, pengamatan, dan refleksi. Hasil penelitian pada siklus I akan diadakan perbaikan proses pembelajaran pada siklus II. Instrumen dalam penelitian ini adalah perangkat pembelajaran yang terdiri dari silabus, RPP dan LKS. Instumen pengumpulan data terdiri dari tes hasil belajar siswa dan lembar observasi.

\section{HASIL PENELITIAN}

\section{Hasil Belajar}

Elfi Rahmi, Penerapan Model Pembelajaran Kooperatif Tipe Talking Stick Dapat Meningkatkan Hasil Belajar IPS Siswa Kelas Vb SDIT Insan Utama Pekanbaru 
Ketuntasan hasil belajar IPS siswa dari ulangan harian siklus I dan ulangan harian siklus II mengalami peningkatan. Untuk melihat ketuntasan pembelajaran IPS siswa berdasarkan skor dasar, ulangan harian siklus I, ulangan harian siklus II pada materi peristiwa 10 November 1945 di Surabaya, dan pertempuran Ambarawa, Peristiwa Bandung Lautan Api, dan Pertempuran Medan Area setelah diterapkan model pembelajaran kooperatif tipe talking stick di kelas V B SDIT Insan Utama Pekanbaru 2017/2018, selengkapnya dapat dilihat pada tabel dibawah ini:

\section{Tabel 2}

Peningkatan Hasil Belajar

\begin{tabular}{|c|c|c|c|c|c|}
\hline \multirow{2}{*}{ Data } & \multicolumn{4}{|c|}{ Ketuntasan Belajar } & \multirow{2}{*}{ Rata- } \\
\cline { 2 - 5 } & \multicolumn{2}{|c|}{ Individual } & \multicolumn{2}{c|}{ Klasikal } & Ket \\
\cline { 2 - 5 } & Tuntas & \\
\hline Skor Dasar & $(43,48 \%)$ & $(56,52 \%)$ & $43,48 \%$ & Tidak Tuntas & 68,91 \\
\hline Siklus I & $(65,21 \%)$ & $(34,78 \%)$ & $65,21 \%$ & Tidak Tuntas & 76,73 \\
\hline Siklus II & $(86,95 \%)$ & $(13,04 \%)$ & $86,95 \%$ & Tuntas & 82,17 \\
\hline
\end{tabular}

Berdasarkan tabel diatas dapat dilihat bahwa adanya peningkatan hasil belajar IPS dari skor dasar ke siklus I yaitu dari rata-rata 68,91 ke 76,73 dengan persentase peningkatan sebesar $11,34 \%$ Peningkatan hasil belajar IPS dari skor dasar ke UH II yaitu dari rata-rata 68,91 menjadi $82,17 \%$ dengan persentase peningkatan sebesar $19,24 \%$.

Ketuntasan belajar dikatakan tuntas apabila nilai hasil belajar siswa mencapai 75. Dari tabel 2 ketuntasan belajar siswa dari ulangan harian siklus I dan siklus II mengalami peningkatan dari skor dasar yang diperoleh hanya 10 siswa yang tuntas dan 13 siswa tidak tuntas. Setelah penerapan model pembelajaran kooperatif tipe Talking Stick pada siklus I secara individu 15 siswa tuntas dan 8 siswa tidak tuntas. Tidak tuntasnya ini disebabkan siswa belum terbiasa dengan kehadiran peneliti dan belum mengerti dengan penerapan model pembelajaran kooperatif tipe Talking Stick sehingga proses pembelajaran tidak berjalan lancar, materipun susah dipahami dan hasil belajarpun kurang maksimal.

Pada siklus II ketuntasan belajar siswa mengalami peningkatan yakni siswa yang tuntas berjumlah 20 orang dan 3 orang tidak tuntas dengan ketuntasan 
klasikal dinyatakan tuntas, karena telah mencapai $75 \%$ dari jumlah siswa yang mencapai KKM.

Berdasarkan tabel ketuntasan klasikal telihat peningkatan skor sebelum dan sesudah tindakan. Dari skor dasar persentase klasikal hanya $43,48 \%$ dinyatakan belum tuntas karena masih dibawah $75 \%$. Sedangkan pada siklus I terjadi peningkatan yakni $65,21 \%$ tetapi belum dinyatakan tuntas karena belum sesuai dengan nilai yang ditentukan maka dilakukan siklus selanjutnya. Pada siklus II ketuntasan klasikal melebihi nilai yang ditetapkan yakni $86,95 \%$ dengan keterangan tuntas.

\section{Keterlaksanaan Model Pembelajaran Talking Stick}

\section{Aktivitas Guru}

Berdasarkan data hasil pengamatan aktivitas guru yang terdiri atas 4 kali pertemuan pembelajaran, 2 kali ulangan dari 2 siklus, selama proses pembelajaran berlangsung dengan penerapan model pembelajaran kooperatif tipe Talking Stick di kelas VB SDIT Insan Utama Pekanbaru tahun pelajaran 2017/2018. Secara keseluruhan pelaksanaan model pembelajaran kooperatif tipe talking stick dilakukan dengan baik. Untuk lebih jelasnya dapat dilihat pada analisis data observasi aktivitas guru dalam tabel di bawah ini.

Tabel 3

Analisis Lembar Pengamatan Aktivitas Guru Pada Siklus I dan II

\begin{tabular}{|c|c|c|c|c|}
\hline \multirow{2}{*}{ Aspek } & \multicolumn{2}{|c|}{ Siklus 1 } & \multicolumn{2}{c|}{ Siklus 2 } \\
\cline { 2 - 5 } & P1 & P2 & P1 & P2 \\
\hline Presentase & $75 \%$ & $79,5 \%$ & $83,33 \%$ & $87,5 \%$ \\
\hline Kategori & Cukup & Baik & Baik & Sangat Baik \\
\hline
\end{tabular}

Berdasarkan tabel tersebut dapat dilihat aktivitas guru selama 4 kali pertemuan selalu mengalami peningkatan, hal ini dapat dilihat dari persentase pelaksanaan model pembelajaran kooperatif tipe Talking Stick. Pada pertemuan pertama siklus dengan persentase $75 \%$ dikategorikan cukup dan pertemuan kedua dengan persentase $79,5 \%$ kategori baik. Pada siklus kedua pertemuan pertama dengan persentase $83,33 \%$ kategori baik. Pada pertemuan kedua dengan persentase $87,5 \%$ dikategorikan sangat baik. Peningkatan aktivitas guru 
yang terjadi disetiap pertemuan ini dikarenakan guru selalu memperbaiki kekurangan-kekurangan yang dilakukan pada setiap pertemuan.

\section{Aktivitas Siswa}

Berdasarkan data hasil pengamatan aktivitas siswa yang terdiri atas 4 kali pertemuan pembelajaran, 2 kali ulangan dari 2 siklus, selama proses pembelajaran berlangsung dengan penerapan model pembelajaran kooperatif tipe Talking Stick di kelas VB SDIT Insan Utama Pekanbaru tahun pelajaran 2017/2018. Peningkatan aktivitas siswa dilihat dari tabel berikut.

\section{Tabel 4}

Aktivitas Siswa Pada Siklus I dan II

\begin{tabular}{|c|c|c|c|c|}
\hline \multirow{2}{*}{ Aspek } & \multicolumn{2}{|c|}{ Siklus 1 } & \multicolumn{2}{c|}{ Siklus 2 } \\
\cline { 2 - 5 } & P1 & P2 & P1 & P2 \\
\hline Presentase & $58,33 \%$ & $70,83 \%$ & $79,16 \%$ & $91,66 \%$ \\
\hline Kategori & Kurang & Cukup & Baik & Sangat Baik \\
\hline
\end{tabular}

Berdasarkan tabel diatas dapat dilihat aktivitas siswa selama 4 kali pertemuan selalu mengalami peningkatan, hal ini dapat dilihat dari persentase pelaksanaan model pembelajaran kooperatif tipe Talking Stick . pada siklus 1 pertemuan pertama didapat persentase $58,33 \%$ dengan kategori kurang sedangakan pertemuan kedua mengalami peningkatan yaitu dengan persentase $70,83 \%$ dengan kategori cukup. Pada sikuls 2 pertemuan pertama didapat persentase $79,16 \%$ kategori baik. Kemudian pada pertemuan kedua mengalami peningkatan dengan persentase $91,66 \%$ dengan kategori sangat baik.

\section{PEMBAHASAN HASIL PENELITIAN}

Berdasarkan analisis data pada tabel penelitian ini maka diperoleh kesimpulan tentang data hasil belajar siswa melalui data aktivitas guru dan siswa serta ulangan harian disetiap akhir siklus, yang menunjukkan adanya peningkatan dalam setiap siklusnya.

Ketuntasan skor dasar dapat dilihat perbandingan hasil belajar siswa setelah penerapan model pembelajaran kooperatif tipe Talking Stick dengan yang menerapkan model pembelajaran sesuai dengan penelitian sebelumnya yang 
dilakukan oleh Nofrianti, Rati (2013) menyatakan bahwa penerapan model pembelajaran kooperatif tipe talking stick dapat meningkatkan hasil belajar IPS siswa.

Berdasarkan hasil belajar pada skor dasar yang diambil dari rata-rata ulangan IPS siswa sebelum diterapkan model pembelajaran kooperatif tipe Talking Stick adalah 68,91 dengan persentase 43, 48\% dengan kategori ketuntasan klasikal tidak tuntas. Kemudian peneliti menerapkan model pembelajaran kooperatif tipe Talking Stick pada 2 kali siklus dengan 4 kali pertemuan menyampaikan materi dan 2 kali ulangan harian. Setelah dilakukan tes ualngan harian pada siklus 1 kemampuan siswa meningkat dengan nilai rata-rata kelas 76,73 dengan persentase ketuntasan klasikal 65,21\% dengan kategori ketuntasan klasikal tidak tuntas. Kemudian peneliti melakukan diskusi dengan observer untuk melakukan perbaikan proses belajar mengajar pada siklus berikutnya. Pada siklus II mengalami peningkatan hasil belajar yaitu perolehan rata-rata kelas menjadi 82,17 dengan persentase ketuntasan 86,95\% dengan kategori ketuntasan klasikal tuntas. Setelah diadakan pembelajaran dengan penerapan model kooperatif tipe Talking Stick pada mata pelajaran IPS, secara perlahan cara belajar siswa berubah menjadi meningkat dan mencapai KKM. Secara umum berdasarkan analisis tindakan terdapat peningkatan skor hasil belajar, sehingga dapat disimpulkan bahwa penerapan model pembelajaran kooperatif tipe Talking Stick dalam pelajaran IPS dapat meningkatkan hasil belajar siswa kelas VB SDIT Insan Utama Pekanbaru khususnya materi Peristiwa 10 November 1945 di Surabaya, Pertempuran Ambarawa, Peristiwa Bandung Lautan Api, dan Pertempuran Medan Area.

Berdasarkan data tentang aktivitas guru selama proses pembelajaran terlihat jelas bahwa aktivitas guru telah sesuai dengan perencanaan, terbukti dengan adanya peningkatan aktivitas guru pada setiap siklusnya. Pada pertemuan pertama siklus 1 diperoleh skor aktivitas guru yaitu 17 dengan persentase $75 \%$ dengan kategori cukup. Pada pertemuan kedua siklus 1 skor aktivitas guru meningkat menjadi 19 dengan persentase $79,16 \%$ dengan kategori baik. Pada pertemuan pertama siklus II diperoleh skor aktivitas guru yaitu 20 dengan persentase $83,33 \%$ kategori baik. Selanjutnya pertemuan kedua siklus II skor 
aktivitas guru meningkat menjadi 21 dengan persentase $87,5 \%$ kategori sangat baik karena guru sudah memenuhi kritikan dari pengamat sehingga proses pembelajaran sudah bisa diatasi. Proses pembelajaran dapat berjalan dengan baik apabila ada interaksi yang baik antara siswa dan guru sehingga akan bekerjasama untuk dapat tercapainya tujuan pembelajaran.

Aktivitas siswa pada setiap pertemuan di siklus I dan II juga meningkat. Berdasarkan tabel peningkatan persentase aktivitas siswa pada pertemuan pertama siklus I adalah 14 dengan persentase 58,33\% kategori kurang,pada tahap ini siswa belum terbiasa dengan kehadiran peneliti dan model pembelajaran yang digunakan, dan mengalami peningkatan pada pertemuan kedua meningkat sebanyak 17 dengan presentasi 70,83\% dengan kategori cukup. Meskipun meningkat tetapi kegiatan siswa belum optimal karena siswa tidak fokus. Pada pertemuan pertama siklus II meningkat sebesar 19 dengan presentasi 79,16\% dengan kategori baik, siswa sudah semangat dalaam belajar sehingga pertemuan kedua siklus II meningkat sebanyak 21 dengan presentasi $91,66 \%$ dengan kategori sangat baik karena kerja sama dan ketertiban sudah meningkat, siswa tidak lagi bermain sendiri dan telah bekerja sama dengan teman lainnya.

Aktivitas siswa sudah meningkat karena siswa sudah terbiasa dan telah telah memahami langkah-langkah penerapan model pembelajaran kooperatif tipe Talking Stick sehingga siswa lebih memahami materi yang sedang dipelajari. Aktivitas guru dan siswa sangat berperan untuk ketuntasan siswa baik secara individu maupun klasikal.

Berdasarkan hasil di atas maka mendukung hipotesis yang diajukan yaitu jika diterapkan model pembelajaran kooperatif tipe Talking Stick maka dapat meningkatkan hasil belajar IPS siswa kelas VB SDIT Insan Utama Negeri Pekanbaru. Jadi, disimpulkan bahwa hipotesis tindakan dapat diterima.

\section{SIMPULAN}

Berdasarkan hasil analisa data yang telah disajikan pada Bab IV, maka dapat disimpulkan bahwa penerapan model pembelajaran kooperatif tipe Talking Stick dapat meningkatkan hasil belajar IPS siswa kelas VB SDIT Insan Utama Pekanbaru. Peningkatan hasil belajar dapat dilihat pada data berikut: 
1. Peningkatan hasil belajar siswa terlihat pada nilai rata-rata. Dari skor dasar ke UH I dengan nilai rata-rata meningkat dari 68,91 menjadi 76,73 dengan peningkatan sebesar $11,34 \%$. Sedangkan peningkatan berikutnya antara skor dasar ke UH II dengan nilai rata-rata dari 68,91 menjadi 82,17 dengan peningkatan sebesar $19,24 \%$.

2. Aktivitas guru selama proses pembelajaran dengan menerapan model pembelajaran kooperatif tipe Talking Stick mengalami peningkatan. Pada siklus I pertemuan 1, skor aktivitas guru adalah $75 \%$ (cukup) meningkat pada pertemuan 2 sebanyak 79,5\% (baik) lalu mengalami peningkatkan sebanyak 83,33\% (baik) pada siklus II pertemuan 2 menjadi 87,5\% (sangat baik). Sedangkan aktivitas siswa selama proses pembelajaran dengan penerapan model pembelajaran kooperatif tipe Talking Stick juga mengalami peningkatan dari siklus I pertemuan I yakni 58,33\% (kurang) meningkat sebanyak 70,83\% (cukup) pada siklus II pertemuan 1 menjadi 79,16\% (baik) lalu meningkat pada siklus II pertemuan 2 sebanyak $91,66 \%$ (sangat baik).

\section{DAFTAR PUSTAKA}

Depdiknas. 2006. Kurikulum Tingkat Satuan Pendidikan: Standar Isi Mata Pelajaran IPS. Jakarta: Depdiknas.

Guslinda, Witri.G (2018) Penerapan Model Pembelajaran Kooperatif Tipe Make A Match untuk Meningkatkan Hasil Belajar IPS Siswa Jurnal Tunjuk Ajar,Vol. 1, No. 1 ,

Hermita, N. 2017. Pengembangan Visual Multimedia Supported Conceptual Change Text (VMMVSCCText) MateriKelistrikan dan Kemagnetan Untuk Pengajaran Remedial Berorientasi Konstruksi-Rekonstruksi Konsepsi IImiah Mahasiswa Calon Guru SD. (Tesis). Universitas Pendidikan Indonesia. (Tidak Diterbitkan).

Nofrianti, Rati. 2013. Penerapan Model Pembelajaran Kooperatif Tipe Talking Stick Untuk Meningkatkan Hasil Belajar IPS Siswa Kelas IV SD Negeri 164 Pekanbaru. Skripsi tidak dipublikasikan. FKIP Universitas Riau.

Suharsimi, A. 2012. Prosedur Penelitian Suatu Pendekatan Praktik. Rineka Cipta. Jakarta. 
Suprijono, Agus. 2014. Cooperative Learning: Teori dan Aplikasi Paikem. Yogyakarta: Pustaka Pelajar.

Wahidmurni. 2017. Metodologi Pembelajaran IPS: Pengembangan Standar Proses Pembelajaran IPS di Sekolah/Madrasah. Yogyakarta: Ar-ruzz Media. 